\title{
Ruslands tragedie: Et folk der længes efter forandring, og et styre der kæmper imod
}

Af Lilia Shevtsova

Ruslands personbårne magtapparat (det russiske styre) har udvist en forbavsende evne til at overleve, også selvom det befinder sig på randen af opløsning. Det er lykkedes Kreml at forlænge sin overlevelse ved ikke bare at genoplive gamle myter, men ved også at skabe usikkerhed om gældende normer og den geopolitiske situation og udnytte Vestens forvirring.

Efter præsident Putins genindsættelse i marts 2018 synes det russiske styre at have mistet pusten. Der har dog ikke vist sig noget alternativ til styret overhovedet. Vil Rusland endelig kunne finde en vej ud af den blindgyde samfundet er fanget i, og i så fald hvornår? Svaret på dette spørgsmål vil have indflydelse ikke blot på den vej, Rusland vil tage, men også på den globale udvikling.
Rusland - et blændværk

Rusland er mester i at skabe vrangforestillinger om sig selv. Den mest spektakulære var sovjetologiens sammenbrud, da den helt op til det øjeblik, hvor landet begyndte at falde fra hinanden, fastholdt, at Sovjetunionen var urokkelig og klippefast. Efter Sovjetunionens kollaps har Ruslandseksperter i både Rusland og i Vesten i det store hele holdt fast i denne form for myteskabende adfærd.

Den populære fortælling om Rusland er den dag i dag problematisk. For det første er der en udbredt Putindyrkelse i både den akademiske og journalistiske diskurs. Jeg tænker her på mange iagttageres forsøg på at identificere Rusland med Putin, hvorigennem de påtager sig rollen som hans psykiater og forsøger at trænge ind i hovedet på ham og fortælle deres publikum om hans inderste tanker og

Dr. Lilia Shevtsova, er Associate Fellow ved Russia and Eurasia Program ved Chatham House. 
mest hemmelige planer. Putindyrkelsen smigrer uden tvivl den russiske leders ego og giver ham mulighed for at betragte resten af verden med foragt. Men hjælper det os til at forstå Kremls politik, hvad der ligger til grund for det russiske styres modstandskraft eller de forskellige strømninger i det russiske samfund?

Ironisk nok har Putins psykoanalytikere igen og igen taget fejl i deres forudsigelser om Putins handlinger og deres udlægning af hans motiver. Det har dog ikke fået dem til at skifte plade. Putin er således 'den mest magtfulde leder i verden', 'Putin forstår verden', 'en fantastisk skikkelse'. Det er bare nogle få citater fra Vestens fortælling om Putin. En sådan beundring af den russiske leder er foruroligende. Hvordan kan det være, at 'den mest magtfulde leder' vil tillade, at hans land bliver underkastet sanktioner og sat ud på sidelinjen?

Hvorfor er Vesten så fascineret af Kremls magt? Afspejler det en egen frustration over det liberale demokrati, eller er det bevis for, at man stiller sig tilfreds med enkle svar på svære spørgsmål? Hvad grunden end er, så fordrejer det Vestens opfattelse af situationen i Rusland.

Her er nogle få eksempler mere på udbredte fejlantagelser om Rusland:

'Rusland ønsker en konfrontation med Vesten'. Kremls retorik er rettet mod den indenrigspolitiske scene for at skabe et billede af Rusland som et land omgivet af fjender: Der er ikke andre måder, hvorpå man kan sam- le russerne om fædrelandets fane, end ved at kalde på den militære patriotisme. Når det gælder forholdet til udlandet, var Vladimir Putin dog indtil for nylig usædvanligt forsonende i sit forsøg på at undgå yderligere fjendtlighed mellem Rusland og Vesten.

Det betyder selvfølgelig ikke, at Kreml har trukket i land; det betyder, at Kreml har ønsket at genoptage en (for Moskva) positiv dialog med Vesten uden at tabe ansigt. Desuden indser Kreml udmærket, at en dialog med Vesten i højere grad vil tillade det russiske styre at overleve end en faktisk, og ikke fingeret, konfrontation.

Kreml bliver derudover nødt til at tage hensyn til ændringer i den offentlige stemning. Ruslands udenrigspolitik er ved at miste et af sine stærkeste instrumenter: den antivestlige mobilisering. I en opinionsunders $\varnothing$ gelse i maj 2018 svarede 39 pct. af de adspurgte, at Putin skulle prioritere at forbedre levestandarden, mens kun fem pct. sagde, at han skulle styrke Ruslands position i verden og forsvare det mod dets fjender, og kun to pct. anså sikkerhedsspørgsmål for at være præsidentens vigtigste opgave.

Og endnu en påstand, der støttes af både russiske og vestlige kommentatorer: 'Ruslands status som stormagt er central for Ruslands identitet.' Det er helt rigtigt, at det ville være mærkeligt for russere at betragte deres land som

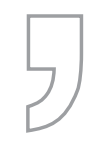

Nu hvor Ukraine har forladt den euroasiatiske skude, og Hviderusland, Kasakhstan og Usbekistan søger et tættere forhold til Vesten og forfølger en særlig dagsorden i forhold til Kina, har det euroasiatiske projekt mistet momentum. 
en stat som alle andre. Landet er dog i dag splittet i dette spørgsmål: 42 pct. af russerne siger, at de gerne ville se Rusland som en stormagt, der er frygtet af andre lande; 56 pct. ønsker at se Rusland som en stormagt, der kan sikre befolkningens velfærd, og de mener ikke, at Rusland bør være et af de mest magtfulde lande i verden. Det udgør vestlige iagttagere er blevet forført af deres klang. Samtidig må alle forsøg på 'at knytte' Rusland til Kinas ambitiøse projekt 'Den nye Silkevej' (nu kaldet 'Et bælte, en vej') ses som endnu en gang fupmageri.

Der kan måske nok være tale om en 'tilknytning', men det bliver kun i den grad, det kan hjælpe Kina til at udvikle en infrastruktur, der kan forbinde det med Europa. Er Rusland indstillet på at fungere som en bro for Kina? Næppe! Mens Kina ønsker at bygge en ny opfattelse blandt russere af begrebet stormagtsstatus og giver anledning til en ny opfattelse af Rusland.

Der er et par andre myter, der holder stand. Kommentatorer bliver ved med at diskutere Rusland som centrum for den Store Euroasiatiske Verden. Geopolitik og ikke mindst det euroasiatiske projekt har været en udvej for analytikere, der ikke har vidst, hvad de ellers skulle sige om udviklingstendenser i Rusland. Men nu hvor Ukraine har forladt den euroasiatiske skude, og Hviderusland, Kasakhstan og Usbekistan søger et tættere forhold til Vesten og forfølger en særlig dagsorden i forhold til Kina, har det euroasiatiske projekt mistet momentum.

En anden udbredt tanke blandt dem, der forsøger at udpege et nyt globalt projekt for Rusland, er idéen om en kinesisk-russisk alliance. 'Efter at være blevet afvist af Vesten har Rusland vendt sig mod Asien og fundet en ledende samarbejdspartner i Kina' - sådan lyder de nye toner fra russiske pro-Kreml analytikere, og bro til Europa, ønsker Putins Kreml at skubbe Rusland i den anden retning, hvilket gør hele spørgsmålet om tilknytning til et begrebsmæssigt rod. Desuden, hvorfor skulle Kina gøre sig nogen ulejlighed med at pleje en svindende stormagts forfængelighed?

Eksperterne har endnu ikke forstået den sammensatte farveskala i det russiske landskabsmaleri. Både de, der søger konfrontation, og mere opportunistiske stemmer beskriver kun brudstykker af den russiske virkelighed.

De misforståelser, der uvægerligt må opstå ud af disse fragmentariske betragtninger, er ikke alene med til at underminere Vestens politik over for Rusland. De er også med til at forvirre Kreml med hensyn til Vestens intentioner. Udviklingen i de sidste ti år viser, at Kremls handlinger på den internationale scene ikke kun har været motiveret af indenrigspolitiske spørgsmål, men også af Kremls opfattelse af, hvordan Vesten ser Rusland og præsident Putin. 


\section{Grundlæggende udfordringer}

Som en mester i forstillelse er det russiske styre blevet fanget i en række samfundsudfordringer, det ikke har noget svar på.

Den første udfordring er manglen på en samlende idé. Den russiske stat har historisk været legitimeret ikke af en 'interesse' men af en 'idé', som ses som en afspejling af et historisk imperativ. Den ide om et historisk imperativ har fungeret som en erstatning for nationen som begreb og som den samlende kraft i staten. I dag kan hverken integration med Europa eller det euroasiatiske projekt, forsvaret af fædrelandet eller stormagtsstatus bruges effektivt som det russiske imperativ. I 2014 førte militaristisk patriotisme og fjendebilleder i flere år til national samling omkring fædrelandets fane. I dag er det russiske samfund og den russiske elite ikke indstillet på dette offer.

Folket ønsker ikke at leve i en belejret fæstning, hvilket er meget problematisk for Kreml. I 2018 svarede 56 pct. af de adspurgte i en undersøgelse, at Rusland burde styrke dets relationer til Vesten (21 pct. talte for at øge Ruslands afstand til Vesten).

Den anden udfordring vil være at gøre op med den overlevelsesmekanisme, der kunne kaldes 'triaden'. Denne overlevelsesmodel har omfattet tilsyneladende uforenelige politikker: inddæmning af Vesten, den russiske elites personlige integration $\mathrm{i} \mathrm{Ve}-$ sten og Kremls udnyttelse af Vestens ressourcer. To af triadens politikker - inddæmning af Vesten og udnyttelse af dens ressourcer - blev finpudset
I stedet for at indføre vestlige normer i Rusland udnyttede den russiske elite Vestens åbenhed til at forfølge egne kapitalinteresser samtidig med, at Rusland blev lukket for indflydelsen fra liberale værdier.

under både zar- og sovjetstyret. To moderniseringsbølger i Rusland under henholdsvis Peter den Store og Stalin blev opnået gennem vestlig teknologi og intellektuel påvirkning.

Den russiske elites personlige integration i Vesten (bankkonti og pengeoverførsler, $\mathrm{k} ø \mathrm{~b}$ af fast ejendom i vestlige lande m.m.) begyndte efter Sovjetunionens sammenbrud og viste, hvordan russerne kunne udnytte globaliseringen: I stedet for at indføre vestlige normer i Rusland udnyttede den russiske elite Vestens åbenhed til at forfølge egne kapitalinteresser samtidig med, at Rusland blev lukket for indflydelsen fra liberale værdier. Det ironiske ved dette er, at det ikke lykkedes de liberale demokratier at hjælpe Rusland til forandring men til at bevare en konstruktion, der er fremmed over for vestlige værdier.

Ruslands annektering af Krim og krigen med Ukraine i 2014, der førte til Vestens sanktioner som svar, blev Triadens endeligt. Præsident Putin havde næppe forventet dette, idet han tilsyneladende havde håbet, at Vesten ville bære over med Ukraine ligesom den havde båret over med krigen med Georgien.

Den tredje udfordring, som Rusland står overfor, er oprustningens blindgyde. Det russiske styre har i årevis grundlæggende bygget på et krigs- 


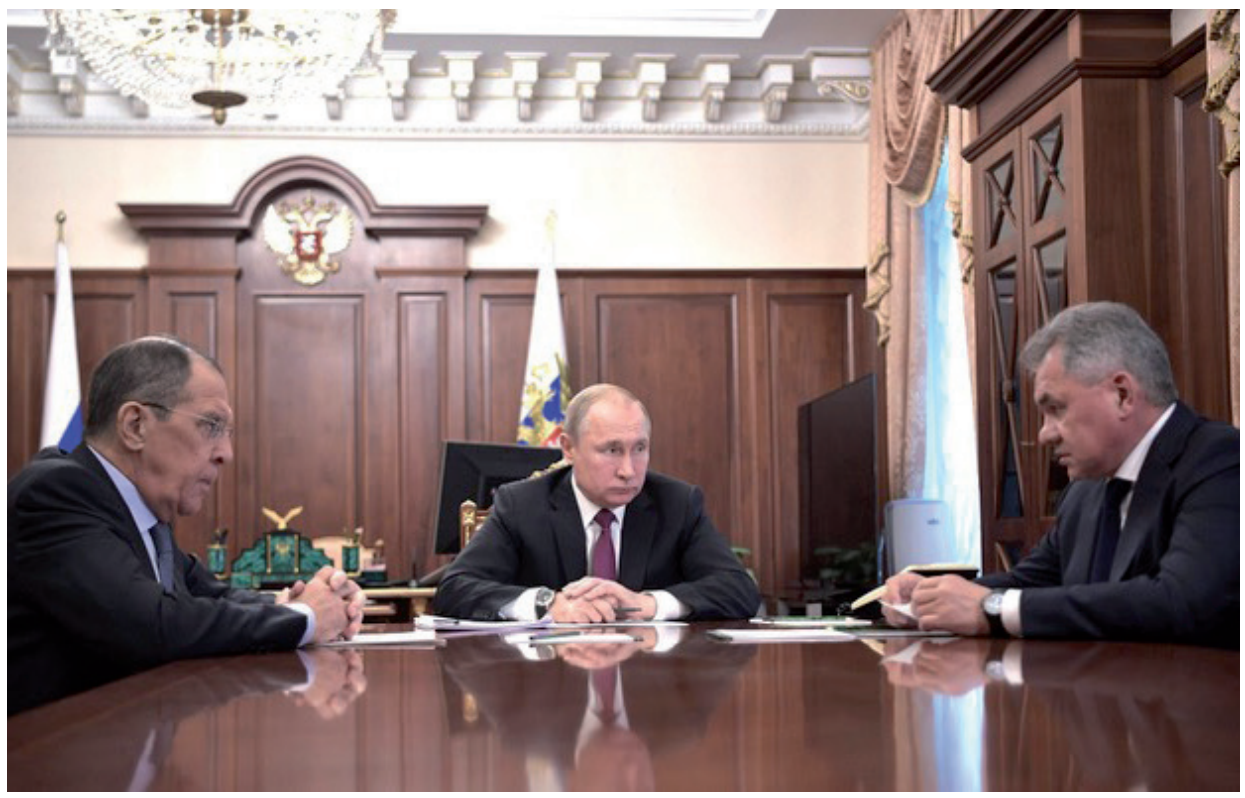

FOTO: Præsidentens Presse- og Informationskontor

Vladimir Putin med udenrigsminister Sergei Lavrov (tv.) og forsvarsminister Sergei Shoigu (th).

paradigme. Rusland gik fra det ene krigsprojekt til det andet, og krig har sammen med en militaristisk konsolidering altid været et nøgleparameter for Ruslands eksistens.

Sovjetunionens sammenbrud satte ikke en stopper for dette militaristiske paradigme. Den russiske politiske klasse har ikke været i stand til at finde en anden idé at samle nationen om og er vendt tilbage til stormagtsdrømme og militarisme. Men på grund af de økonomiske forhold og begrænsninger har Kreml ikke råd til at deltage i et våbenkapløb. Den russiske ledelse er klar over, at Ruslands militærbudget på 46 mia. dollar ikke kan konkurrere med USA, der kan bruge 700 mia.
Rusland er derfor endt $i$ en vanskelig situation: Det er ikke i stand til at fortsætte en reel militær konkurrence med dets ærkerival, men det kan på den anden side heller ikke komme ud af sin brug af krig som handlingsmodel. Dette fører reelt set til, at der fra Kremls side forsøges kompenseret for den begrænsede hårde magt ved enten at optrappe atomvåbenretorikken eller (og) søge efter hybride konfrontationsmekanismer (cyberangreb og misinformationskrig, indblanding i de vestlige samfunds interne anliggender).

Den fjerde og sidste udfordring, som Rusland står overfor, er præsident Putin selv. Rusland er nået til et punkt, hvor den siddende magt er be- 
gyndt at underminere styret. Ikke alene kan Putins lederskab ikke sikre stabilitet i Rusland, det kan heller ikke garantere elitens interesser. Ved at have bragt Rusland i en situation, hvor det er i permanent konfrontation med Vesten, og have gjort recession til russisk dagligdag kan Putin ikke længere ændre dette, uden at det fremstår som et nederlag, hvilket hans omdømme ikke kan bære.

Men manglen på en gnidningsløs overgang til en ny leder og den eksisterende Kremlledelses stædige $\varnothing n$ ske om at forsvare sin magt har ført til et politisk morads: Putin kan ikke gå selv, og samtidig er der ikke noget politisk alternativ, der kan udfordre ham.

\section{Kremls dagsorden}

Kremls vigtigste mål er at gøre Rusland i stand til at overleve en lang recession og bevare kontrollen over befolkningen. Kreml har bevidst valgt en strategi for afmodernisering og dermed sat tidligere forsøg på at modernisere Rusland i bero. Dette skift var ventet: Enhver forandring kunne bringe samfundet til fald som dominobrikker.

Over for befolkningen har den regerende elite i stedet for mobilisering, der kræver at man har en samlende idé, valgt at eksperimentere med demobilisering, det vil sige en svækkelse af horisontale netværk, der samler folk om bestemte mål. Et atomiseret og desorienteret samfund præget af gensidig mistro og voldelighed er et sam- fund, der er nemt at manipulere. Råddenskab, nedværdigelse og darwinistiske impulser er ved at blive en russisk livsstil.

Den russiske økonomi er begyndt at stagnere. Manglen på en retsstat og et uafhængigt retssystem gør det umuligt at etablere et konstruktivt investeringsklima og reel økonomisk vækst. Selv de høje oliepriser (omkring 80 dollar per tønde) kan ikke genstarte den økonomiske motor. Økonomien vil dog på grund af et arkaisk økonomisk system og dets voksende isolation fra moderne økonomiske strømninger kunne overleve i lang tid uden at gå i opløsning.

Den økonomiske recession får levestandarden til at falde. 12 pct. af den russiske befolkning lever i ekstrem fattigdom. I 2019 vil der ifølge det russiske handelskammer være over 20 mio. mennesker, der lever under fattigdomsgrænsen. Faldet i levestandard sker samtidig med en yderligere voksende social ulighed. For eksempel: månedslønnen for medlemmer af bestyrelsen i olieselskabet Rosneft er 4,3 mio. dollar, gennemsnitslønnen i Rusland ligger på 425 dollar. 46 pct. af Ruslands formuer er ejet af omkring 10 pct. af befolkningen - det danner grobund for en social eksplosion.

Ruslands udenrigspolitik har altid tjent en indenrigspolitisk dagsorden ved at fjerne opmærksomheden fra interne ulykker og problemer og sikre eksterne ressourcer. Kreml har med succes forfulgt en eksemplarisk postmoderne politik, der omfatter ufor- 
enelige størrelser, og som skal opbløde de iboende modsætninger mellem principper og normer, mellem krig og fred, mellem rigtigt og forkert, mellem virkelighed og efterligning, mellem allieret og fjende og mellem love og lovløshed. Staten kan som urostifter nemt starte en kamp for fred. Meget putinsk og postmoderne!

Kreml har under præsident Putin opnået nogle få taktiske sejre, der har ført Rusland tilbage på den globale arena som den ledende fredsforstyrrer, der har indflydelse på den globale sikkerhedsdagsorden, og i nogle vestlige lande som en faktor i indenrigspolitiske magtkampe (et af Kremls succesfulde tiltag har været at redde den syriske diktator Assad og tvinge Vesten til at acceptere ham som en nødvendighed i det mindste indtil videre).

Kremls taktiske sejre vil dog blive til strategiske katastrofer. For eksempel har Kremls måde at hævde sig på den globale scene hjulpet til at samle Vesten til at indføre sanktioner; det har revitaliseret NATO; det har øget Vestens befolkningers mistro til Rusland og samlet den amerikanske elite i en antirussisk bevægelse. De russiske satellitstater er utrygge og prøver at undgå at komme alt for tæt på Moskvas favntag. Men mest katastrofalt er det, at Moskva på denne måde selv har været med til at svække sin overlevelsesmodel, der skulle sikre udnyttelse af vestlige ressourcer.

I dag står Kreml over for en svær opgave: Det forsøger at retablere status quo fra før Krimkrisen for at kunne vende tilbage til sit tidligere overlevelsesmønster, men det ønsker, at det skal ske på dets egne betingelser. Det er blevet en enorm udfordring. Kremls gamle princip, hvor man optrappede spændte situationer for så at nedtrappe og tvinge det 'samlede Vesten' til at acceptere ens krav, virker ikke længere. Kompromiser med Vesten dur heller ikke: Enhver forhandling og aftale kræver, at Kreml giver noget igen, og her er man ikke parat til at give indrømmelser.

Fra 2016 til først i 2018 har Kreml tyet til en 'vent og se'-position i forventning om, at Vesten i sidste ende ville give sig lidt, og forsøgt ikke at provokere Vesten unødigt. Som Skripalsagen viste, er det for Kreml blevet svært at finde den rette balance mellem handlekraft og dialog. Udviklingen i efteråret 2018 viser, at det ikke er lykkedes Moskva at nedbryde Vestens fælles sanktionspolitik. Ydermere er støtten til Putins udenrigspolitik svækket på hjemmefronten: i 2016 støttede 22 pct. af de adspurgte den, i 2018 kun 16 pct.

Kreml har dog stadig muligheder at spille på. Den tyske kansler Angela Merkels gradvise tilbagetrækning, den franske præsident Emmanuel Macron, der er ved at miste opbakning, Brexit, Trump, der svækker det transatlantiske fællesskab, 'trojanske heste' som Ungarn, der svækker EU's sammenhængskraft - det giver alt sammen Putin et vist spillerum. Hvilket betyder, at han spiller med musklerne ved at teste de nye hypersoniske missiler 'Avangard' i årets sidste dage.

Det hypersoniske missilsystem viser Kremls forsøg på at anvende militærafpresning til at tvinge Vesten til at acceptere Ruslands forståelse af de globale regler. 
Den franske adelsmand AstolpheLouis-Léonor, Marquis de Custine, skrev i sin beskrivelse af sin oplevelse af Rusland i 1839: "Peter den Store har gjort sit folk til en hoer af tavse soldater ... Det russiske kejserdømme er ensbetydende med kadaverdisciplin, med en stat under belejring, der skal opfattes som et samfunds normaltilstand."

I det 21. århundrede har Vladimir Putin forsøgt at omdanne Rusland til et land som det, de Custine beskrev i det 19. århundrede. Det stiller os ikke alene over for en politisk og historisk afvigel-

\section{Interregnum: En tid uden for tiden}

middelalderligt paradigme og indånde det 21. århundredes vinde.

Det russiske styre vil dog selv med svækket modstandskraft evne at halte videre. Der er adskillige 'stabilitetsfaktorer', der holder det oven vande.

For det første må man holde sig for øje, at selv blandt Putins kritikere frygter man et nyt '1991', det vil sige at staten går i opløsning, hvis centralmagten bryder sammen. Der er også usikkerhed med hensyn til, hvorvidt Rusland som en samling af forskellige 'befolkningsbrikker' (se bare på Tjetjenien) kan holdes samlet under et demokratisk styre.

For det andet er libera-

\section{Kreml kan ikke håndtere den eksisterende} korruption eller den regerende klasses særinteresser og gennemgående straffrihed. Den sociale uretfærdighed er blevet en stærk eksplosiv faktor.

se men viser også, hvordan Rusland er løbet $t ø r$ for incitamenter og derfor må ty til fortiden for at overleve.

Styret er trådt ind i en ny cyklus i kampen for sit liv. Det har forkastet at efterligne vestlige institutioner og samarbejde med Vesten og står nu igen frem som Vestens antitese og som undertrykker af individualismen, der har været den centrale fremskridtsdrivkraft i det 21. århundrede. Det ligner et forsøg på at stoppe tiden. Krigene mod Georgien og Ukraine, konfrontationer mellem Rusland og Vesten (og det selvom det så skulle aftage en smule) og Kremls tilbagevenden til en militærpatriotisk mobilisering er ikke andet end tegn på styrets manglende evne til at komme ud af et lisme som modernistisk ideologi blevet diskrediteret i Rusland både på grund af det liberale demokratis stagnation og Vestens deltagelse i korrupte aftaler og overenskomster med det russiske og det internationale kleptokrati og på grund af den rolle, som russiske såkaldte liberale i Putins inderkreds har spillet i den autokratiske magtstruktur.

Således har liberale russiske kræfter i regeringen spillet en større rolle $i$ at bevare den russiske personbårne magt end de såkaldte siloviki - repræsentanter for sikkerhedstjenesterne - der med deres ragen til sig og indbyrdes magtkampe kun har været med til at diskreditere og svække styret.

For det tredje synes transformation af de postkommunistiske regimer at være langt mere kompliceret (som det at gå væk fra kommunismen - hotilfældet med Ukraine viser) end bare 
vedsageligt på grund af sammenblandingen af magt og ejendomsret, der efterfølgende er blevet legitimeret af et korrupt retsvæsen. I Ruslands tilfælde bør dertil lægges den svære transformation af en atom- og stormagt.

For det fjerde må man overveje, om russisk demokrati er en mulighed uden Vestens normative anvisninger (fx i Europarådet), som samtidig indebærer, at Rusland må gå med til at afgive suverænitet? Det vil for den russiske opposition være selvmord at gå med til dette.

Når det er sagt, skal også de faktorer, der svækker Ruslands stabilitet, nævnes. Kreml kan ikke håndtere den eksisterende korruption eller den regerende klasses særinteresser og gennemgånde straffrihed. Den sociale uretfærdighed er blevet en stærk eksplosiv faktor. Elitens loyalitet over for Putin personligt og hans ledelsesmagt kan også komme til at vakle, hvis først denne magt ikke længere kan garantere dem deres tidligere sikkerhed og formue.

Derudover ser vi følgerne af 'loven om utilsigtede konsekvenser'. De kræfter, der har hjulpet til at stabilisere styret tidligere, er begyndt at svække det og skaber dermed en situation, hvor der er lagt låg på en boblende gryde. Ved at skabe et politisk Sahara og ikke give befolkningen mulighed for at komme til orde, skubber den folk ud i gaderne. Ved at afvise forandring oppefra giver Kreml kun plads til én form for forandring - gennem revolution.

Der er tegn på, at Ruslands vej ud af den postsovjetiske reinkarnation af et personbåret styre vil blive svær og smertefuld. I øjeblikket er Kreml låst fast og kan ikke længere komme ud af slædesporet - det kan ikke andet end fortsætte sin inddæmningspolitik over for Vesten, da det ikke har nogen anden fælles national ideologi, der ville kunne retfærdiggøre dets greb om magten.

Kreml kan ikke længere bevare sin magt uden et vist mål af tvang: liberalisering ville indebære, at styret mister magt og påtager sig et ansvar for fortidens synder. Samtidig forstår Kreml, at hverken eliten eller befolkningen har lyst til en ny kold krig eller andre konfrontationer. Ledelsen må også forstå, at undertrykkelse i en situation med voksende social utilfredshed kan give bagslag.

\section{Fremtiden?}

Det er ikke det eneste, Rusland har at slås med. En anden ting er, at på den ene side kan det personbårne styre ikke imødekomme moderne tiders udfordringer, på den anden kan det ikke reformeres ovenfra - der er ikke nogen reformatorer højt oppe i magtsystemet, kun 'stabilisatorer' og 'medløbere'. Desuden kan enhver reform, som det sås med Gorbatjovs perestrojka, udløse ikke bare en opløsning af den 'vertikale' magt og ustabilitet, men også true statens sammenhængskraft.

Man kan spørge sig selv: hvordan så med Vladimir Putins popularitet? Den er begyndt at falde. I november 2017 sagde 59 pct. af de adspurgte, at de havde tillid til Putin. I september 2018 var det tal kun 39 pct. I november 2018 sagde 83 pct. af de adspurgte, at Putin 'var ansvarlig for alle Rus- 
2) Socialt og politisk pres kan faktisk ende med at være den eneste måde at tvinge nøgleaktører i en forældet verdensorden til at holde op med at blokere for forsøg på at opbygge nye regler og genopbygge styret.

lands problemer' (kun 6 pct. sagde at Putin handlede 'rigtigt'). 27 pct. af de adspurgte havde tillid til regeringen, 23 pct. til Dumaen. Disse udmeldinger synes ikke at afspejle en massiv støtte til magthaverne. Selv de der siger, at de stadig bifalder præsidentens handlinger, gør det ofte ud af gammel vane og en frygt for, at lederens fald vil føre til statens kollaps.

Parallelt med dette siger 83 pct. af russerne, at de ønsker forandringer. Tilsyneladende vil Rusland ikke længere være i stand til at undgå social og politisk uro. Kaos truer endnu en gang Rusland. Som Fukuyama skrev: "nogle gange er vold den eneste måde at fordrive dybt rodfoestede aktører, der blokerer for institutionel forandring." Russiske iagttagere udelukker heller ikke muligheden for en borgerkrig eller revolution. Socialt og politisk pres kan faktisk ende med at være den eneste måde at tvinge nøgleaktører i en forældet verdensorden til at holde op med at blokere for forsøg på at opbygge nye regler og genopbygge styret således, at det kan åbne sig for nye interesser. Man kan med rette frygte denne vej også. Rusland har en katastrofal tradition for vold, der ender med et nyt enmandsvælde, som ofte viser sig mere ondskabsfuldt og undertrykkende end det sidste. Det kan dog i sidste ende blive den eneste udvej.

Vil nogle af pragmatikerne fra den gamle elite og oppositionen kunne finde en løsning, før vrede og kaos for alvor bryder ud? Det er stadig uklart, om pragmatikerne reelt vil kunne blive del af en transformationsproces, eller om de vil arbejde for at holde Rusland i dets aktuelle dødvande til den bitre ende de har været dybt involveret i styrets overlevelsesprojekt indtil videre. Og det er også uklart, hvad der skal til for at samle den opposition, der er imod styret. Men den nuværende stilstand er bedragerisk. Stormen nærmer sig, og den vil kunne fremskynde styrets undergang.

Det russiske statsstyres endelige skæbne vil få umådelig store konsekvenser for verdensordenen og alle dens forskellige dimensioner: europæisk sikkerhed, atomvåbensikkerhed, internationale institutioner og deres ageren, energisikkerhed, stabilitet i Ruslands nabolande, hvilke veje globale aktører som fx Kina vil vælge og endelig folkestemningen i liberale demokratier, og hvordan de anskuer deres fremtid og verdens i det hele taget.

Sandhedens time for Rusland kan vitterlig komme til at lukke et kapitel i verdenshistorien og åbne et nyt.

(Oversat af Lotte Jansen) 